\title{
Lower-Tropospheric Warming and Drying in Tropical Mesoscale Convective Systems: Implications for the Problem of Cumulus Parameterization
}

\author{
By Richard H. Johnson \\ Department of Atmospheric Science, Colorado State University, Fort Collins, CO 80523 \\ (Manuscript received 2 April 1986, in revised form 22 July 1986)
}

\begin{abstract}
Observations from the International Winter Monsoon Experiment (Winter MONEX) have been used to determine temperature changes in the lower troposphere beneath the stratiform components of tropical mesoscale convective systems. It is found that while the apparent heat source $Q_{1}$ in the lower troposphere beneath the stratiform cloud systems is negative (due to hydrometeor melting and evaporation), the time tendency of dry static energy $(\partial \bar{s} / \partial t)$ is positive. This low-level warming is a result of mesoscale downdrafts within the mesoscale convective systems. The warming and drying at low levels in such systems may contribute importantly to temperature and moisture changes in large-scale tropical disturbances. The effects, if important, will need to be considered in the development of schemes for the parameterization of cumulus convection.
\end{abstract}

\section{Introduction}

Horizontal temperature variations in the tropical troposphere are typically very small. Even in tropical disturbances where condensational heating on the synoptic scale can be quite large $\left(5-10^{\circ} \mathrm{C}\right.$ day $\left.^{-1}\right)$, temperature changes are minor because latent heating is largely offset by adiabatic cooling (e.g., Wallace, 1971). Within tropical easterly waves, temperature fluctuations in the troposphere are typically $\sim 1^{\circ} \mathrm{C}$ or less (Riehl, 1969; Reed and Recker, 1971; Thompson et al., 1979).

Temperature changes in tropical convective disturbances are given by the thermodynamic energy equation as a small residual of two large terms of opposite sign (condensational heating and adiabatic cooling). This fact complicates efforts to parameterize the effects of convection in large-scale prediction models. Inaccuracies in the representation of the heating effects of convection in cumulus parameterization schemes can quickly lead to large errors in predicted temperature fields.
For this reason it is important to examine factors that contribute to temperature fluctuations in tropical disturbances. Riehl (1954) has shown that waves in the easterlies are cold core at low levels and warm core aloft. Easterly wave composite studies (Reed and Recker, 1971) in the west Pacific and east Atlantic (Thompson, et al., 1979) confirmed these findings. The lower tropospheric cooling has been attributed by Riehl (1969) and Reed and Recker (1971) to evaporative cooling in the areas of precipitation. The warm core aloft is presumably a consequence of latent heat release.

Recent studies of tropical mesoscale convective systems have shown that significant temperature changes over large areas can occur in the lower troposphere beneath the stratiform components of these systems (Houze, 1977; Zipser, 1977; Johnson and Kriete, 1982; Johnson and Nicholls, 1983; Gamache and Houze, 1985). It is the purpose of this paper to examine the possible impact of such systems on the temperature field in tropical disturbances using 
recent results from the International Winter Monsoon Experiment (Winter MONEX). The relevance of these findings to the problem of cumulus parameterization will be discussed.

\section{Background}

Following Yanai et al. (1973), with appropriate modifications to include the effects of ice, we define an apparent heat source $Q_{1}$ by

$$
\begin{aligned}
Q_{1}= & \frac{\partial \bar{s}}{\partial t}+\underset{\sim}{\bar{v}} \cdot \nabla \bar{s}+\bar{\omega} \frac{\partial \bar{s}}{\partial p} \\
= & -\frac{\partial}{\partial p} \overline{\left(\omega^{\prime} s^{\prime}\right)}+L_{v}(\bar{c}-\bar{e}) \\
& +\left(L_{v}+L_{f}\right)\left(\bar{d}-\bar{s}_{*}\right)+L_{f}(\bar{f}-\bar{m})+\bar{Q}_{R}
\end{aligned}
$$

where $s=c_{p} T+g z$ is the dry static energy, $Q_{R}$ is the net radiative heating rate, $L_{v}$ and $L_{f}$ are the latent heats of vaporization and fusion and $c, e, d, s_{*}, f$ and $m$ are rates of condensation, evaporation, deposition, sublimation, freezing and melting. Overbar refers to an average over a large-scale area.

Computations of $Q_{1}$ for the stratiform components of mesoscale convective systems observed during Winter MONEX have recently been reported by Johnson and Young (1983). A schematic illustrating convective and stratiform components of a mature mesoscale convective system and their associated heating profiles is given in Fig. 1. Such systems, which often have lifetimes of $\sim 12-18 \mathrm{~h}$, evolve from initial cumulus-scale $(\sim 1-10 \mathrm{~km})$ elements and later expand to a structure schematically shown in Fig. 1 (Leary and Houze, 1979a). In the latter stage of the life cycle only the stratiform component remains. The heating profiles for the convective and stratiform components have been deduced from idealized cloud budgets by Houze (1982) and from Winter MONEX rawinsonde data by Johnson and Young (1983) and Johnson (1984). In the convective area there is heating at all levels due to net condensation with a maximum in the mid-troposphere. The heating profile for the stratiform area is characterized by heating in the mid- to upper troposphere due to condensation, and cooling in the lower troposphere due to melting and evaporation.

Well-defined mesoscale circulations are observed to be associated with the stratiform components of mesoscale convective systems: an updraft in the mid- to upper troposphere and a downdraft (driven by melting and evaporation) in the lower troposphere (Zipser, 1969; Houze, 1977; Zipser, 1977; Brown, 1979; Leary and Houze, 1979b; Gamache and Houze, 1982, 1983 and 1985; Johnson, 1982; Churchill and Houze, 1984; Houze and Rappaport, 1984). Despite the melting and evaporation at low levels, considerable warming and drying atop the boundary layer are observed near the back edge of the trailing stratiform region, leading to an "onion" shape of the temperature-dew point sounding plot there (Zipser, 1977).

For strong squall lines observed in GATE (the Global Atmospheric Research Program
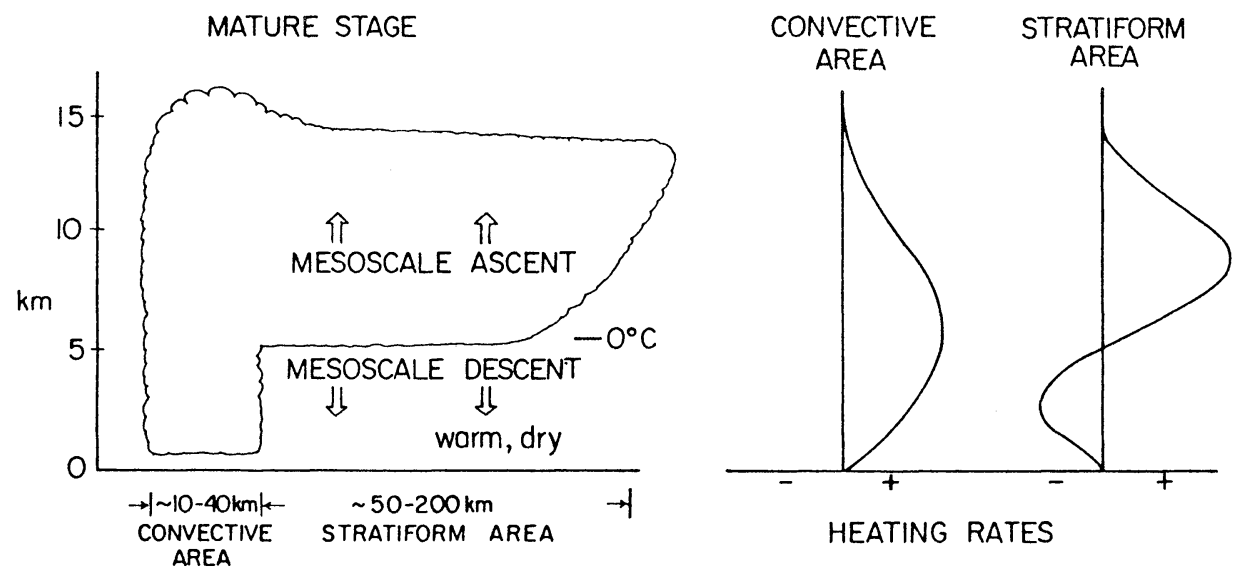

Fig. 1. Schematic of mature stage of a mesoscale convective system. Typical heating profiles for the convective and stratiform areas are illustrated. 
Atlantic Tropical Experiment), the low-level warming in the mesoscale downdraft can be significant: $\sim 2$ to $3^{\circ} \mathrm{C}$ at about $1 \mathrm{~km}$ over a considerable area (e.g., Johnson and Nicholls, 1983). Cooling is obserbed near the surface (Zipser, 1977), which can be attributed to spreading cool air from saturated convective-scale downdrafts. Similar lower-tropospheric warming has been reported beneath the stratiform portions of mesoscale convective systems in Winter MONEX (Johnson and Kriete, 1982). The lowlevel warming and drying are most pronounced in the squall lines, but still exist in the more common nonsquall systems, though with smaller amplitude (Zipser et al., 1981). An illustration of this warming for convective disturbances on 12 September 1974 in GATE is shown in Fig. 2 (adapted from Johnson and Nicholls, 1983). Two mesoscale warm areas at $1 \mathrm{~km}$ are seen: one behind the stratiform cloud or mesoscale anvil of the squall line (at the position of the surface wake depression) and the second in the near vicinity of a slowly-moving convective line in advance of the squall (Gamache and

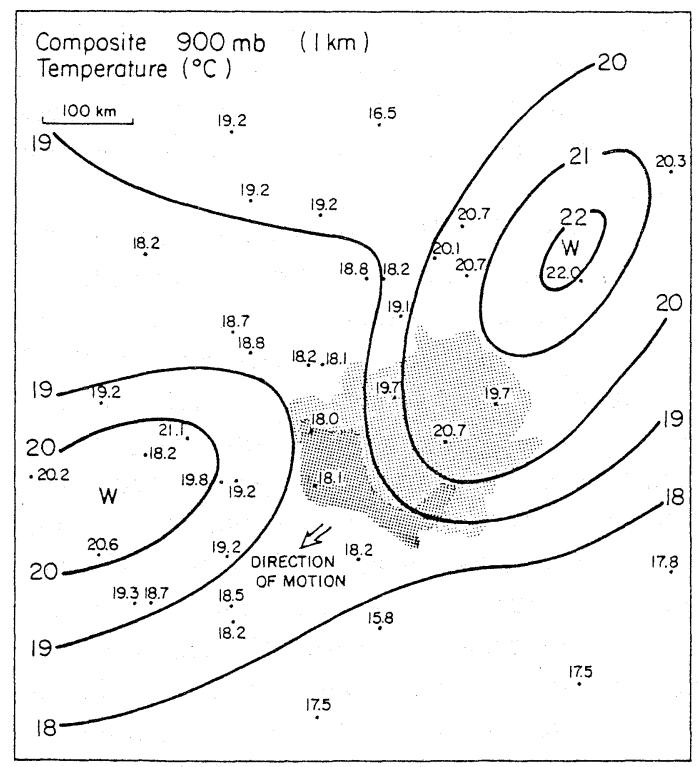

Fig. 2. Temperature at $900 \mathrm{mb}(1 \mathrm{~km})$ in 12 September 1974 GATE composite squall line (adapted from Johnson and Nicholls, 1983). Dark shading indicates composite squall radar echo, light shading the trailing stratiform region (from Gamache and Houze, 1982). Plotted values are from GATE ship array soundings.
Houze, 1985). The warming is most intense behind the squall line, but is still quite pronounced in the vicinity of the pre-squall convective line. This presquall lower-tropospheric warming may have been a consequence of an earlier squall line which passed through the GATE ship array on 11 September. Significant drying is also observed at $1 \mathrm{~km}$ in the squall line wake, with relative humidities as low as 50\% (Johnson and Nicholls, 1983).

The significant modification of the temperature field beneath the stratiform components of mesoscale convective systems and the large areas involved suggest that such systems may be important contributors to lower tropospheric temperature changes in tropical disturbances. This statement may be especially true considering that a large fraction of the total rainfall in tropical disturbances is from the stratiform component, estimated to be approximately $40 \%$ in the eastern Atlantic (Cheng and Houze, 1979; Gamache and Houze, 1983; Leary, 1984; Houze and Rappaport, 1984) and the southern South China Sea (Churchill and Houze 1984). We next explore possible implications of this phenomenon for the large-scale circulation using Winter MONEX observations.

\section{Winter MONEX heat budgets for stratiform components}

In Johnson and Young (1983) heat budgets for the stratiform components of seven mesoscale convective systems that occurred over the South China Sea during Winter MONEX were presented. These systems developed along the north coast of Borneo during the nighttime hours as a result of an interaction of the Borneo land breeze and the northeast monsoon flow over the South China Sea. They later propagated to the west-northwest across a triangular array of Soviet ships. Using six-hourly sounding ship data, $\partial \bar{s} / \partial t$ from (1) has been computed (employing a centered difference procedure) for the seven cases. The results are shown in Fig. 3 . While there is considerable noise in the profiles, warming in the lower troposphere is seen in each case. Systematic variations at other levels are not apparent.

The individual events are next composited 


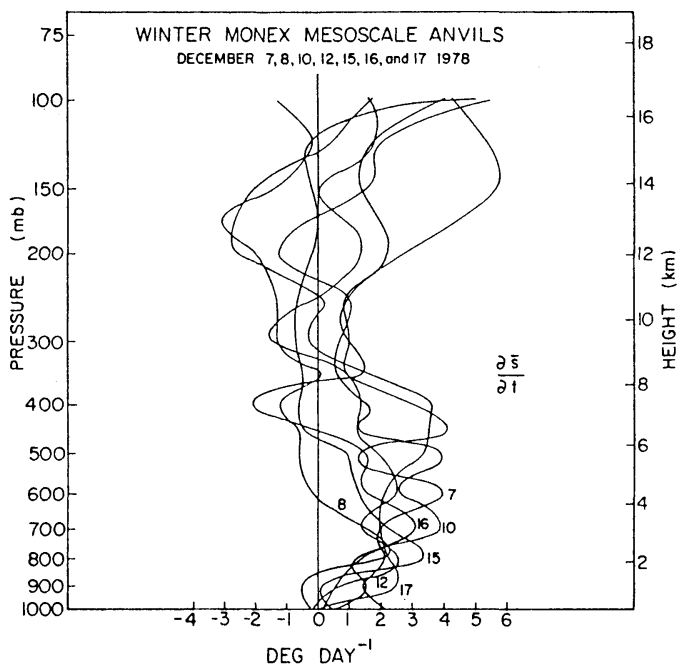

Fig. 3. Storage of dry static energy $(\partial \bar{s} / \partial t)$ for seven Winter MONEX mesoscale anvils (stratiform components of mesoscale convective systems).

and displayed with the composite $Q_{1}$ profile from Johnson and Young (1973) in Fig. 4. The diabatic processes of melting and evaporation in the lower troposphere yield a negative heating $\left(Q_{1}\right)$, but the atmospheric response is a warming $(\partial \bar{s} / \partial t$ positive). This unique situation where the atmospheric response has the opposite sign of the forcing is a consequence of dynamical processes on the mesoscale. Mesoscale downdrafts driven, in part, by precipitation evaporation (Brown, 1979) lead to adiabatic warming over-compensating evaporative cooling at low levels beneath the stratiform clouds. Miller and Betts (1977) argue that the subsidence in this region is dynamically forced by spreading cool air at the surface; however, there does not appear to be general agreement on this matter. This peculiar behavior of mesoscale convective systems clearly complicates efforts to parameterize effects of deep convection on the low-level temperature and moisture fields in large-scale prediction models.

\section{Implications for cumulus parameterizations}

If the stratiform components of tropical mesoscale convective systems are as prevalent as field experiments of the last several decades suggest, then their impact on the lower-tropospheric temperature (and moisture) field of tropical disturbances can probably not be ig-

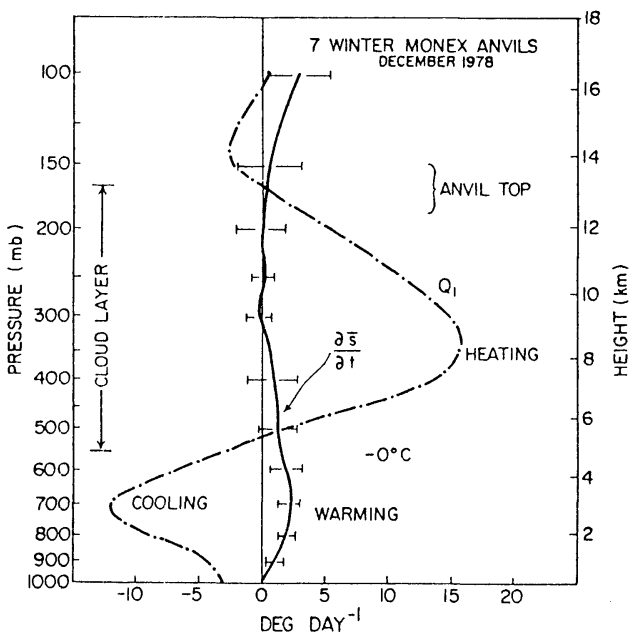

Fig. 4. Composite storage of dry static energy $(\partial \bar{s} / \partial t)$ for seven Winter MONEX mesoscale anvils. Horizontal bars indicate standard deviation. Also shown is $Q_{1}$ profile from Johnson and Young (1983).

nored. Certainly their important contribution to the total tropical rainfall suggests their impact may be significant. A simple parameterization relating warming to heating will not be generally successful because mesoscale circulations complicate the response to heating. The extensive areas influenced by the stratiform components make their contribution to large-scale changes in temperature and moisture probably not negligible.

One possible effect of such systems might be evident in the observed temperature structure of tropical easterly waves. For example, easterly wave composites for the western Pacific (Reed and Recker, 1971) and the eastern Atlantic (Thompson et al., 1979) show temperature anomalies in the lower troposphere having amplitudes of 0.1 to $0.5^{\circ} \mathrm{C}$. Convective systems within easterly waves are both squall and nonsquall in nature, though nonsquall systems are the most prevalent. However, the amplitude of the lower-tropospheric warming and drying is much greater for the squall systems (Zipser et al., 1981). It has been demonstrated by Payne and McGarry (1977) that, at least in the eastern Atlantic, squall lines exist in a preferred region of the easterly waves, well ahead of the wave trough (most occur in the region between the wave ridge axis and the position of maximum northerly flow). The occurrence of such features 
in a preferred region of tropical waves may have a net impact on the temperature anomaly structure of the composite wave. Careful analysis of each event is, of course, needed to confirm the above suggestion and data do not presently exist to determine unambiguously the impact of mesoscale convective systems on the temperature anomaly field within the waves.

Despite our inability to define precisely the impact of many mesoscale convective systems with attendant low-level warming and drying on the large-scale temperature structure of tropical disturbances, it is apparent that potential exists for this impact to be important. If such is the case, it suggests that the problem of parameterization of moist convection in a conditionally unstable atmosphere is much more complicated than is often generally regarded. If the modification of the large-scale temperature and moisture fields by tropical disturbances is determined in an important way by mesoscale downdrafts, whose intensity may be significantly influenced by factors such as vertical wind shear, thermodynamic stability, storm life history, etc., then there is little hope for achieving a simple representation of convective effects in large-scale models. If such models explicitly resolve mesoscale systems, then the lowertropospheric warming and drying should be included in the simulations.

\section{Summary and conclusions}

The existence of pronounced lower-tropospheric warming and drying in association with the stratiform component of tropical mesoscale convective systems compounds the already difficult problem of the treatment of cumulus convection in large-scale numerical prediction models. Diagnostic heat budget results from Winter MONEX show that while there is a negative lower-tropospheric apparent heat source $Q_{1}$ beneath the stratiform cloud systems, the time tendency of dry static energy $(\partial \bar{s} / \partial t)$ is positive. Hydrometeor melting and evaporation impose a cooling, but the atmospheric response is a warming due to mesoscale circulations within the convective system. The observations reported in this study suggest that mesoscale dynamical processes associated with tropical cloud clusters may have an important impact on the lower- tropospheric temperature and moisture fields in large-scale tropical disturbances. If so, convective parameterizations for large-scale models which neglect such processes may incur serious errors even if the effects of cumulus clouds are properly represented.

\section{Acknowledgements}

Thanks go to Gail Watson for typing the manuscript. This research has been supported by the National Science Foundation, Division of Atmospheric Sciences under grant ATM 8507961 .

\section{References}

Brown, J.M., 1979: Mesoscale unsaturated downdrafts driven by rainfall evaporation: A numerical study. J. Atmos. Sci., 36, 313-338.

Cheng, C.-P. and R.A. Houze, Jr., 1979: The distribution of convective and mesoscale precipitation in GATE radar echo patterns. Mon. Wea. Rev., 107, 1370-1381.

Churchill, D.D. and R.A. Houze, Jr., 1984: Development and structure of winter monsoon cloud clusters on 10 December 1978. J. Atmos. Sci., 41, 933-960.

Gamache, J.F. and R.A. Houze, Jr., 1982: Mesoscale air motions associated with a tropical squall line. Mon. Wea. Rev., 110, 118-135.

and - 1983: Water budget of a mesoscale convective system in the tropics. J. Atmos. Sci., 40, 1835-1850.

— and - 1985: Further analysis of the composite wind and thermodynamic structure of the 12 September GATE squall line. Mon. Wea. Rev., 113, 1241-1259.

Houze, R.A., Jr., 1977: Structure and dynamics of a tropical squall-line system observed during GATE. Mon. Wea. Rev., 105, 1540-1567.

, 1982: Cloud clusters and large-scale vertical motions in the tropics. J. Meteor. Soc. Japan, 60, 396-410.

- and E.N. Rappaport, 1984: Air motions and precipitation structure of an early summer squall line over the eastern tropical Atlantic. J. Atmos. Sci. 41, 553-574.

Johnson, R.H., 1982: Vertical motion in near-equatorial winter monsoon convection. J. Meteor. Soc. Japan, 60, 682-690.

, 1984: Partitioning tropical heat and moisture budgets into cumulus and mesoscale components: Implications for cumulus parameterization. Mon. Wea. Rev., 112, 1590-1601.

Johnson, R.H., and D.C., Kriete, 1982: Thermodynamic and circulation characteristics of winter monsoon tropical mesoscale convection. Mon. Wea. Rev., 110, 1898-1911. 
and M.E. Nicholls, 1983: A composite analysis of the boundary layer accompanying a tropical squall line. Mon. Wea. Rev., 111, 308-319.

and G.S. Young, 1983: Heat and moisture budgets of tropical mesoscale anvil clouds. J. Atmos. Sci., 40, 2138-2147.

Leary, C.A., 1984: Precipitation structure of the cloud clusters in a tropical easterly wave. Mon. Wea. Rev., 112, 313-325.

and R.A. Houze, Jr., 1979: The structure and evolution of convection in a tropical cloud cluster. J. Atmos. Sci., 36, 437-457.

and - 1979b: Melting and evaporation of hydrometeors in precipitation from the anvil clouds of deep tropical convection. J. Atmos. Sci., 36, 669-679.

Miller, M.J. and A.K. Betts, 1977: Traveling convective storms over Venezuela. Mon. Wea. Rev., 105, 833848.

Payne, S.W. and M.M. McGarry, 1977: The relationship of satellite inferred convective activity to easterly waves over west Africa and the adjacent ocean during Phase III of GATE. Mon. Wea. Rev., 105, 413-420.

Reed, R.J. and E.E. Recker, 1971: Structure and properties of synoptic-scale wave disturbances in the equatorial western Pacific. J. Atmos. Sci., 28, 1117-1133.
Riehl, H., 1954: Tropical Meteorology, New York, McGraw-Hill, 392 pp.

- 1969: Some aspects of cumulonimbus convection in relation to tropical weather systems. Bull. Am. Meteorol. Soc., 50, 587-595.

Thompson, R.M., Jr., S.W. Payne, E.E. Recker and R.J. Reed, 1979: Structure and properties of synopticscale disturbances in the intertropical convergence zone of the eastern Atlantic. J. Atmos. Sci., 36, $53-72$.

Wallace, J.M., 1971: Spectral studies of tropospheric wave disturbances in the tropical western Pacific. Rev. Geophys. Space Phys., 9, 557-612.

Yanai, M., S. Esbensen and J.H. Chu, 1973: Determination of bulk properties of tropical cloud clusters from large-scale heat and moisture budgets. $J$. Atmos. Sci., 30, 611-627.

Zipser, E.J., 1969: The role of organized unsaturated convective downdrafts in the structure and decay of an equatorial disturbance. J. Appl. Meteor., 8, $779-815$.

, 1977: Mesoscale and convective-scale downdrafts as distinct components of squall line structure. Mon. Wea. Rev., 105, 1568-1589.

- R.J. Meitín and M.A. LeMone, 1981: Mesoscale motion fields in association with a slowmoving GATE convective band. J. Atmos. Sci., 38, $1725-1750$.

\title{
中規模積雲対流系における下部対流圈の昇温および乾燥化： 積雲対流のパラメタリゼーションへの示唆
}

\author{
Richard H.Johnson \\ コロラド州立大学大気科学教室
}

\begin{abstract}
冬季モンスーン国際実験観測（冬季 MONEX）の資料を用いて熱带の中規模対流系における層状雲下 の下部対流圈温度変化を求めた。層状雲下の非断熱加熱 $Q_{1}$ は負の值を示す（水晶核の融解および蒸発

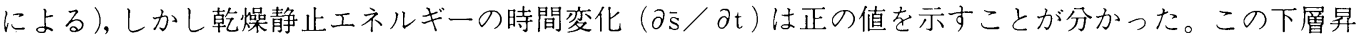
温は中規模対流系中における下降流の結果としてもたらされる。このような対流系における下層の昇温 および乾燥化は，大規模な熱帯擾乱における温度および湿度変化に対して重要な奇与をなし得るもので ある。もしそうであるなら，このような効果は積雲対流のパラメタリゼーションを改善する際に考慮さ れるべき要素となるであろう。
\end{abstract}

